\title{
Review \\ Mesenchymal Stem Cell Therapy in Diabetic Cardiomyopathy
}

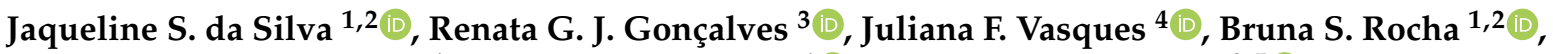 \\ Bianca Nascimento-Carlos ${ }^{1}$, Tadeu L. Montagnoli ${ }^{1}{ }^{1}$, Rosália Mendez-Otero ${ }^{3,5}{ }^{\circledR}$, Mauro P. L. de Sá ${ }^{2}$ \\ and Gisele Zapata-Sudo ${ }^{1,2, *}$
}

1 Programa de Pesquisa em Desenvolvimento de Fármacos, Instituto de Ciências Biomédicas, Universidade Federal do Rio de Janeiro, Av. Carlos Chagas Filho, 373, Rio de Janeiro 21941-902, RJ, Brazil; ssjck@hotmail.com (J.S.d.S.); brunadesouzarocha.98@gmail.com (B.S.R.); biascarlos@yahoo.com.br (B.N.-C.); tmontagnoli@gmail.com (T.L.M.)

2 Instituto do Coração Edson Saad, Faculdade de Medicina, Universidade Federal do Rio de Janeiro, Street Prof. Rodolpho Paulo Rocco, 255, Rio de Janeiro 21941-617, RJ, Brazil; paesleme@hucff.ufrj.br

3 Instituto de Biofísica Carlos Chagas Filho, Universidade Federal do Rio de Janeiro, Av. Carlos Chagas Filho, 373, Rio de Janeiro 21941-170, RJ, Brazil; renata.guedes@biof.ufrj.br (R.G.J.G.); rmotero@biof.ufrj.br (R.M.-O.)

4 Instituto de Ciências Biomédicas, Universidade Federal do Rio de Janeiro, Av. Carlos Chagas Filho, 373, Rio de Janeiro 21941-170, RJ, Brazil; juliana.vasques@icb.ufrj.br

5 Instituto Nacional de Ciência e Tecnologia em Medicina Regenerativa, Av. Carlos Chagas Filho, 373, Rio de Janeiro 21941-902, RJ, Brazil

* Correspondence: gsudo@icb.ufrj.br or gzsudo@gmail.com; Tel.: +55-21-39386505

check for

updates

Citation: da Silva, J.S.;

Gonçalves, R.G.J.; Vasques, J.F.; Rocha, B.S.; Nascimento-Carlos, B.; Montagnoli, T.L.; Mendez-Otero, R.; de Sá, M.P.L.; Zapata-Sudo, G.

Mesenchymal Stem Cell Therapy in Diabetic Cardiomyopathy. Cells 2022, 11, 240. https://doi.org/10.3390/ cells11020240

Academic Editor: Xiaowen Bai

Received: 7 November 2021

Accepted: 22 December 2021

Published: 11 January 2022

Publisher's Note: MDPI stays neutral with regard to jurisdictional claims in published maps and institutional affiliations.

Copyright: () 2022 by the authors. Licensee MDPI, Basel, Switzerland. This article is an open access article distributed under the terms and conditions of the Creative Commons Attribution (CC BY) license (https:// creativecommons.org/licenses/by/ $4.0 /)$.

\begin{abstract}
The incidence and prevalence of diabetes mellitus (DM) are increasing worldwide, and the resulting cardiac complications are the leading cause of death. Among these complications is diabetes-induced cardiomyopathy (DCM), which is the consequence of a pro-inflammatory condition, oxidative stress and fibrosis caused by hyperglycemia. Cardiac remodeling will lead to an imbalance in cell survival and death, which can promote cardiac dysfunction. Since the conventional treatment of DM generally does not address the prevention of cardiac remodeling, it is important to develop new alternatives for the treatment of cardiovascular complications induced by DM. Thus, therapy with mesenchymal stem cells has been shown to be a promising approach for the prevention of DCM because of their anti-apoptotic, anti-fibrotic and anti-inflammatory effects, which could improve cardiac function in patients with DM.
\end{abstract}

Keywords: diabetes mellitus; cardiac remodeling; diabetic cardiomyopathy; mesenchymal stromal cells; pro-inflammatory cytokines; oxidative stress; fibrosis

\section{Introduction}

The incidence and prevalence of diabetes mellitus (DM) worldwide are increasing rapidly, with $19.3 \%$ of the population aged 65-99 diagnosed with DM [1,2], and type 2 (DM2) accounts for $90-95 \%$ of cases [3]. According to the World Health Organization, DM was the ninth cause of global death in 2019, with cardiovascular complications being the main cause of the deaths [4]. Among the cardiac complications is diabetic cardiomyopathy (DCM), which consists of cardiac remodeling characterized by molecular, cellular and interstitial changes, interfering with the size, geometry and function of the heart. DCM includes cell death, changes in energy metabolism and the extracellular matrix, inflammation, oxidative stress, neurohormonal activation and modification in ion transport [5]. DM [6-11] can induce cardiac changes due to remodeling and culminate in cardiac dysfunction, which is independent of other cardiac comorbidities, such as coronary artery disease, hypertension and valvular heart disease [8].

Traditional DM treatment, which can interfere with insulin sensitization and secretion, in addition to causing undesirable side effects [12], fails to prevent and/or treat cardiac remodeling. In recent years, cell therapy is one approach that has been used mainly 
due to its paracrine action, producing immunomodulation and anti-inflammatory and anti-apoptotic activities.

Mesenchymal stem cells (MSCs) are multipotent cells found in almost all adult tissues with the abilities of self-renewal and differentiation, favoring homeostasis and repair, which make them promising tools for regenerative medicine [13]. MSCs show low immunogenicity, which can allow allogeneic cell transplantation, and are home to damaged tissues, where they can engraft and differentiate, promoting repair. However, MSCs have a poor engraftment rate, and cellular replacement is complex and limited. Instead, their therapeutic potential is attributed primarily to the paracrine action of their secretome, which consists of a rich and complex mixture of soluble molecules, such as cytokines, chemokines and growth factors, and extracellular vesicles loaded with proteins, peptides and genetic material (e.g., microRNAs) [14], which can support cell survival and tissue healing. Additionally, preconditioning with hypoxia, growth factors, cytokines or pharmacological agents and genetic modifications can modulate MSCs' survival, proliferation, migration and senescence in order to preserve them and improve their secretory activity, amplifying their therapeutic efficacy [14].

Thus, the present review focuses on the mechanisms involved in DM-induced cardiac remodeling and, consequently, DCM and the potential of MSC therapy to treat DM complications.

\section{Molecular Mechanisms Involved in Diabetes-Induced Cardiac Remodeling}

In the early stages, DCM is characterized by cardiomyocyte apoptosis and myocardial fibrosis with increased deposition of accumulated extracellular matrix (ECM), which leads to rigidity in the diabetic heart, exerting a deleterious effect on diastolic function causing diastolic heart failure with preserved ejection fraction (HFpEF) [15]. Exceeding collagen deposition and the abnormal alignment of cardiomyocytes increase myocardial rigidity resulting from $\mathrm{DM}$ and affect systolic function, which may progress to heart failure with reduced ejection fraction (HFrEF) [16,17]. A high glucose level in DM is responsible for myocardial dysfunction because of the increased fatty acid metabolism, reduced sensitivity to $\mathrm{Ca}^{2+}$ by myofilaments, mitochondrial dysfunction, oxidative stress $[11,15,18-20]$, high levels of advanced glycation end products (AGE) [21], increased inflammation, apoptosis and necrosis [11,22]. These altered properties lead to an imbalance between cell death and survival [6], which, together with increased collagen, fibrosis and hypertrophy [18], culminate in cardiac remodeling.

Hyperglycemia promotes the formation of reactive oxygen species (ROS) and reactive nitrogen species (RNS) [6,7]. ROS induce apoptosis [6] via cytochrome-c-mediated caspase-3 activation [7], which modulates the growth and survival of multipotent cardiac stem cells and progenitor cells (CSPCs) in the heart. Hyperglycemia-induced oxidative stress promotes the increase in mitochondrial ROS production, which triggers cell damage pathways involved in CSPC loss, which, in turn, increases cell death [23,24]. DM induces an increase in the apoptosis/necrosis of myocytes and CSPC, in addition to a reduction in CSPC proliferation, resulting in cardiac myopathy with impaired ventricular function. Oxidative stress is responsible for mitochondria and sarcoplasmic reticulum structural changes, favoring the increase in cell death in animal models of DM [7]. A high plasma superoxide dismutase (SOD) level is detected in DM, which is not accompanied by an increase in plasma glutathione peroxidase (GSH-Px), leading to an increase in oxidative stress and consequent uncontrolled lipid peroxidation [9]. Thus, ROS and malondialdehyde (MDA), a stable end product of lipid peroxidation, are increased in DM, indicating failure of the antioxidant system [25-27], which can result in damage to the cells (Figure 1). The reduction in ROS production and the improvement in antioxidant defense can be promoted by sirtuin 1 (SIRT1), which has nicotinamide adenine-dependent deacetylase activity $[28,29]$. Therefore, the regulation of oxidative stress, inflammation and cardiomyocyte survival by SIRT1 is impaired, whereas cardiac SIRT1 expression is markedly decreased in $\operatorname{DM}[27,30,31]$. 


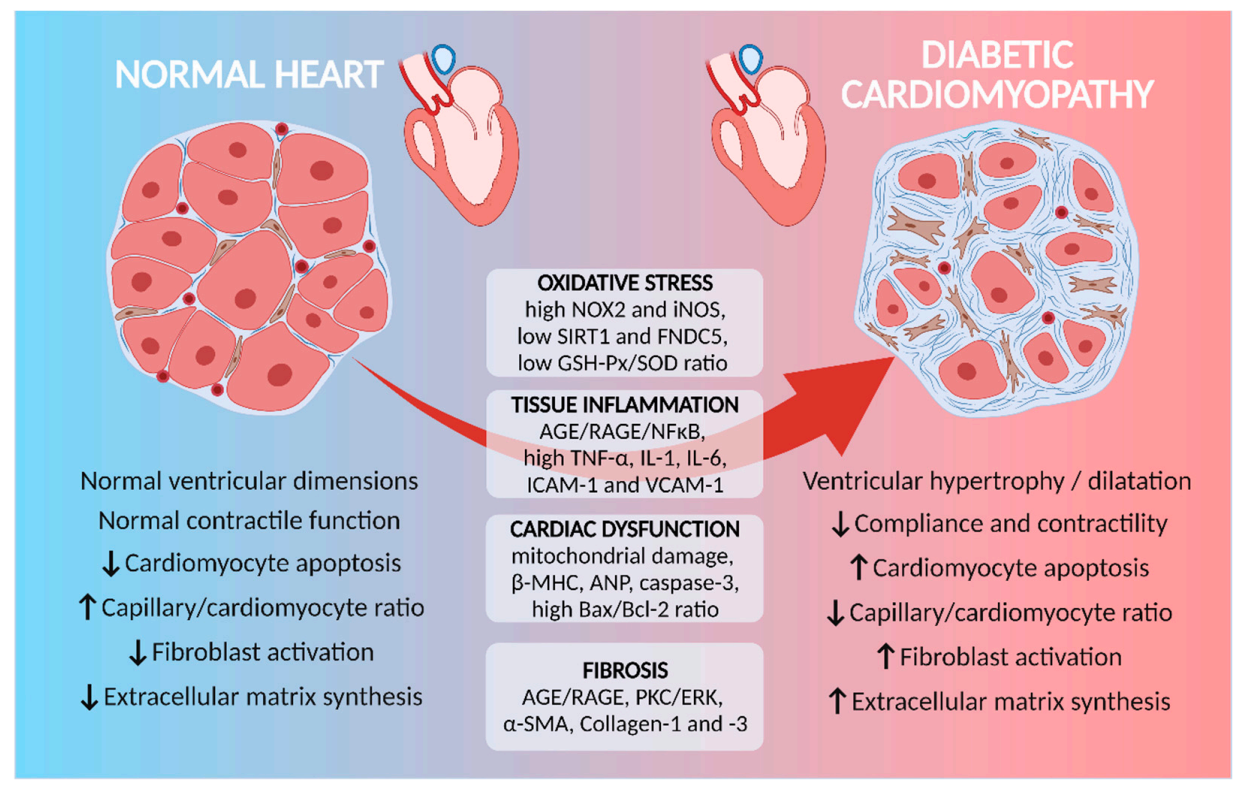

Figure 1. Cardiac functional and morphological alterations in diabetic cardiomyopathy (DCM). Different processes underlie the establishment of DCM, although oxidative stress and tissue inflammation seem to be responsible for maintaining the changes observed in diabetic hearts. Preclinical studies in rodents evidenced alterations in signaling pathways and protein expression related to cardiac dysfunction, which may be relevant targets for the development of new strategies for the treatment of DCM. AGE, advanced glycation end products; ANP, atrial natriuretic peptide; ERK, extracellular signal-regulated kinase; FNDC5, full-length type III fibronectin containing 5; GSH-Px, glutathione peroxidase; ICAM-1, intercellular adhesion molecule-1; IL, interleukin; iNOS, inducible nitric oxide synthase; MHC, myosin heavy chain; NOX2, reduced nicotinamide adenine dinucleotide phosphate-oxidase 2; PKC, protein kinase C; RAGE, receptor for advanced glycation end products; SIRT1, sirtuin 1; SMA, smooth muscle actin; SOD, superoxide dismutase; TNF, tumor necrosis factor; VCAM-1, vascular cell adhesion molecule- 1 . $\uparrow$ increased; $\downarrow$ reduced.

Increased expression of NADPH oxidase 2 (NOX2) and inducible nitric oxide synthase (iNOS) are observed in cardiomyocytes exposed to high levels of glucose and fat, with consequent increase in ROS/RNS formation and cytochrome-c release, leading to cell death (Figure 1). In DM, the levels of full-length type III fibronectin containing 5 (FNDC5) have been reported to be reduced, and they are involved in cardiomyocyte apoptosis [8,32]. The overexpression of FNDC5 reduces NOX2 and iNOS activities, improves glucose tolerance, reverses diastolic dysfunction and attenuates cardiac remodeling, demonstrating a significant role of reduced FNDC5 in cardiac dysfunction observed in DM [8].

High levels of ROS and inflammatory mediators due to hyperglycemia can promote the synthesis of highly reactive carbonyl intermediates from lipid peroxidation, such as glyoxal and methylglyoxal, which lead to the formation of AGE [33]. The activation of AGE/AGE receptor (RAGE) signaling promotes increased ECM synthesis and accumulation in DM [34]. This is due to the increased expression and secretion of various types of collagen and profibrotic factors promoted by AGE, generating ECM crosslinking, which alters the cell-matrix interaction and cell adhesion, as well as modifying the regulation of oxidative stress and inflammation [35]. The AGE-RAGE interaction induces the formation of ROS and activates other signaling proteins, such as extracellular signal-regulated kinases (ERK) $1 / 2$, which, in turn, increase the expression and phosphorylation of activated B cell nuclear factor kappa (NF-kB). Furthermore, AGE can alter SOD expression and impact the expression of proteins related to ECM remodeling [21]. Thus, the increase in ROS, the accumulation of catechol-modified proteins, the expression and secretion of type I and type III collagen and pro-fibrotic activation markers (such as STAT3) explain the occurrence of extracellular matrix remodeling [36]. Increased AGE has also been implicated in fibroblast activation 
and proliferation in DM [37]. Fibroblasts are closely related to cardiac remodeling, since there is an increase in the expression of $\alpha$-smooth muscle actin $(\alpha$-SMA), suggesting the transformation of fibroblasts into a myofibroblast phenotype [38].

P2X7 purinergic receptor (P2X7R) signaling has also been implicated in cardiac remodeling in DM through the modulation of fibrosis and hypertrophy [39]. P2X7R exerts important physiological and pathological effects on the cardiovascular system [40]; its stimulation regulates pro-inflammatory responses in endothelial cells [41,42]. The upregulation of P2X7R in the hearts of diabetic mice and in cardiomyocytes exposed to high glucose content appears to be responsible for the increased activation of protein kinase $C \beta$ (PKC $\beta$ ) and ERK, collagen I and TGF- $\beta$, caspase- 3 and Bax. The inhibition of P2X7R significantly reduces cardiac damage, including fibrosis, apoptosis and hypertrophy, in vivo and in vitro, possibly by reducing the inhibition of the PKC/ERK pathway [39].

Thus, it is clear that the oxidative stress generated by DM promotes cardiac remodeling acting through different signaling pathways in both cardiomyocytes and cardiac fibroblasts, which is a target for the prevention or treatment of DCM.

\section{Myocardial Inflammation and Diabetes-Induced Cardiac Remodeling}

Metabolic disorders, such as DM, induce a systemic inflammatory state, which is reflected in myocardial structure and function [43], progressively leading to a clinically evident cardiomyopathy phenotype, such as HFpEF [44]. Thus, chronic inflammation leads to metabolic reprogramming of the heart and contributes to adverse remodeling and functional impairment [45].

Initially, this proinflammatory state is stimulated by high levels of blood glucose and free fatty acids, acting on different cell types, including resident cardiomyocytes, fibroblasts and macrophages, and, when stimulated, it converges to activate NF- $\mathrm{kB}$ and increase the cytokine expression of TNF- $\alpha$ and IL-6 [46]. Macrophage infiltration in diabetic hearts is associated with a high level of vascular adhesion molecules, such as intercellular adhesion molecule (ICAM)-1 and vascular cell adhesion molecule (VCAM)-1 [43,47], which are related to increased cardiac cellular infiltrate, as well as to a reduction in the concentration of cardiac IL-10 [48]. A high glucose concentration directly activates several pro-inflammatory pathways in cardiac fibroblasts, macrophages and cardiomyocytes due to the induction of the sustained transcription of high mobility protein box 1 (HMGB1) followed by increased NF- $\kappa B$ binding activity with an increased and sustained expression of TNF- $\alpha$, JNK, ERK1/2 and IL-6 [49]. Furthermore, in chronic hyperglycemia, AGE can accumulate in cardiac ECM and increase the expression of pro-inflammatory mediators, including TNF- $\alpha$, IL- 6 , ICAM-1 and CC motif chemokine ligand 2 (CCL2) [43]. AGE also promotes myocardial inflammation by the direct activation of macrophages, promoting the increased expression of TNF- $\alpha$, iNOS and IL- 6 through the RAGE/NF-KB pathway [50,51].

Furthermore, in spontaneously insulin-resistant rats, an increase in the levels of several inflammatory cytokines was observed, such as IL-2, IL-6, IL-1 $\beta$, IL-4, IL-5, IL-12p70, stimulating factor granulocyte and macrophage colonies (GM-CSF), interferon gamma (IFN $\gamma)$ and TNF- $\alpha$. These cytokines can increase the QT interval in diabetic animals, indicating cardiac electrical remodeling. Kv1.3 potassium channels were involved in this process, since treatment with a channel blocker reverses changes in the cardiomyocytes of diabetic rats [52]. Similarly, it was demonstrated in diabetic animals that an electrical remodeling impairs the repolarization of cardiac myocytes due to the increase in TNF- $\alpha$ and IL- $1 \beta$, confirmed by the prevention of the prolongation of the cardiac action potential by the blockade of TNF- $\alpha$ and IL-1 $\beta$ receptors [53].

Transforming growth factor beta (TGF- $\beta$ ) is the main factor involved in cardiac fibrosis, since its expression is increased in cardiomyocyte cells in hyperglycemic conditions, and the increased expression of TGF- $\beta$ is related to a significant increase in collagen synthesis and increased ECM deposition [54]. A possible mechanism proposed for the increase in TGF- $\beta$ in DM is the activation of chemokine receptor type 4 (CXCR4), since the inhibition of this receptor reduces TGF- $\beta$ levels [11]. TGF- $\beta$ /Smad signaling could act via endothelial to 
mesenchymal cell transition (EndMT), playing an important role in the pathogenesis of cardiac fibrosis in DM $[55,56]$. EndMT is an important pathway for changing cell phenotype, promoting the proliferation of cardiac fibroblasts and aggravating cardiac fibrosis in the presence of hyperglycemia [57,58]. In the heart of diabetic rats, upregulation of mesenchymal markers ( $\alpha$-SMA, vimentin and fibroblast-specific protein-1) and downregulation of endothelial markers (CD31 and vascular endothelial cadherin) in peripheral vessels, as well as the reduced phosphorylation of AMPK $\alpha$, are detected in cardiac tissue. The transcription level of EndMT markers (snail 1, snail 2, twist 1 and twist 2) was also elevated in diabetic rat hearts. Importantly, inhibition of the TGF- $\beta /$ Smad pathway can be achieved by dapagliflozin and metformin through AMPK $\alpha$ activation, with the suppression of cardiac fibroblast activity [59].

\section{Epigenetic Involvement in Diabetic Cardiomyopathy}

The influence of metabolic status on gene expression is well known, and research has recently provided mechanistic insights into the association between epigenetic regulation and cardiac pathological remodeling in DCM $[60,61]$. Epigenetic mechanisms involve nucleotide and histone modifications, as well as other transcriptional and translational regulation by non-coding RNAs. These modifications exert long lasting effects, which subside a "hyperglycemic memory" observed in cells from DM patients and animal models $[60,62]$ and may increase the transgenerational risk to cardiometabolic diseases [62,63].

Direct DNA methylation modulates the accessibility of gene promoter sequences to transcription factors, often resulting in gene repression. Cardiomyocytes from diabetic rats display alterations in DNA methylation patterns of cyclin D1 and p21 ${ }^{\mathrm{WAF} 1 / \mathrm{CIP} 1}$ genes when submitted to oxidative stress, which result in increased cell death [64]. Recently, the suppression of androgen receptor transcription was associated with high DNA methyltransferase-1 activity in cardiac fibroblasts in a DM rodent model, which resulted in elevated autophagy and collagen synthesis [65].

Histone methylation, acetylation and phosphorylation are also important mechanisms implicated in gene transcription regulation. Increased activity of histone acetyltransferase (HAT) p300 is observed in rat models of DCM and correlates to the severity of cardiac dysfunction, myocardial hypertrophy and fibrosis [66,67]. The influence of histone acetylation on DCM seems to involve the recruitment of transcriptional regulators, since the treatment with an inhibitor of bromodomain-containing protein-4 (BRD4), apabetalone, decreased the risk of major adverse cardiovascular events and the frequency of hospitalizations after recent acute coronary syndrome in DM2 patients $[68,69]$. In addition to this, BRD4 is overexpressed in DM rodent models, which leads to increased gene expression of hypertrophy and fibrosis markers along with mitochondrial and cardiac dysfunction [70,71].

The pharmacological activation of sirtuins, promoting histone deacetylation, is also reported to attenuate cardiac changes observed in DCM by preventing ROS production and mitophagy, collagen deposition and apoptosis in DM models [62,72-77]. However, the inhibition of other histone deacetylase (HDAC) isoforms is reported to reduce the expression of pro-hypertrophic, pro-inflammatory and pro-fibrotic genes in different models of DCM [74,78-83]. The involvement of histone methylation in controlling gene expression in DCM by modulating cytokine production, gap junction integrity, mitochondrial dysfunction, metabolic imbalance, cardiac cell death and tissue inflammation is certain [84-86]. Along with transcriptional regulation, the role of long non-coding RNAs and micro-RNAs in the modulation of cardiac protein expression in DCM is a topic of great interest [87-90]. Epigenetic mechanisms act in different regulatory pathways in order to control gene expression. Regulation of JunD and $\mathrm{p} 66^{\text {Shc }}$, consequent to changes in promoter and histone methylation patterns, plays an important role in experimental and human DCM [91-93].

\section{Preclinical and Clinical Approaches to MSC in Diabetes-Induced Cardiac Complications}

MSCs were originally obtained from bone marrow [94], which is still the most used source of MSCs for cell-based therapy in preclinical and clinical trials in a wide range of 
diseases [95]. However, they can also be isolated from multiple sources, including fat, skin, muscle and the heart. In recent years, MSCs derived from neonatal tissues (the placenta and umbilical cord) have been widely explored in cell therapy research, as they can be easily and non-invasively obtained with no pain or risk [96]. MSCs are identified by a set of standard criteria, which ascertain their equivalence: (1) plastic adherence under standard culture conditions; (2) expression of CD105, CD73 and CD90 surface markers and lack of expression of hematopoietic progenitor markers CD45, CD34, CD14/CD11b, CD79 $\alpha / C D 19$ and HLA-DR; and (3) differentiation into osteoblasts, adipocytes and chondroblasts [97].

MSCs can differentiate into insulin-producing cells (IPCs) both in vitro and in vivo, which underlies their potential for treating DM [98]. The transplantation of IPCs derived from different types of MSCs in vitro is effective in regulating blood glucose levels in experimental diabetic animals [99-101]. However, although MSCs migrate to the pancreas, the differentiation into IPCs is minimal, and it is not the explanation for the possible regenerative effects induced by cell therapy. On injured pancreatic islets, beneficial effects are consequent to the immunomodulatory, anti-inflammatory and anti-apoptotic actions of the molecules secreted by MSCs, which protect endogenous $\beta$-cells, stimulate their regeneration and proliferation and ameliorate insulin resistance, reversing hyperglycemia, the main determinant of DCM [102]. Regarding cardiac repair, MSCs have protective and regenerative effects in several types of cardiovascular diseases [103]. They can differentiate into cardiomyocytes, endothelial cells and vascular smooth muscle cells [104], but, again, rather than cellular replacement, tissue repair seems mainly related to MSCs' secretome, through which they suppress inflammatory responses and induce neovascularization, resulting in cardiac tissue preservation [105]. In addition, MSCs also have an anti-fibrotic effect, decreasing cardiac fibroblast activity and collagen deposition, and they promote endogenous regeneration by stimulating cardiac resident stem cells and cardiac progenitors. Therefore, the anti-diabetic properties of MSCs combined with their cardioprotective features make their use promising for the treatment of DCM. The major effects of MSCs therapy for DCM are illustrated in Figure 2.
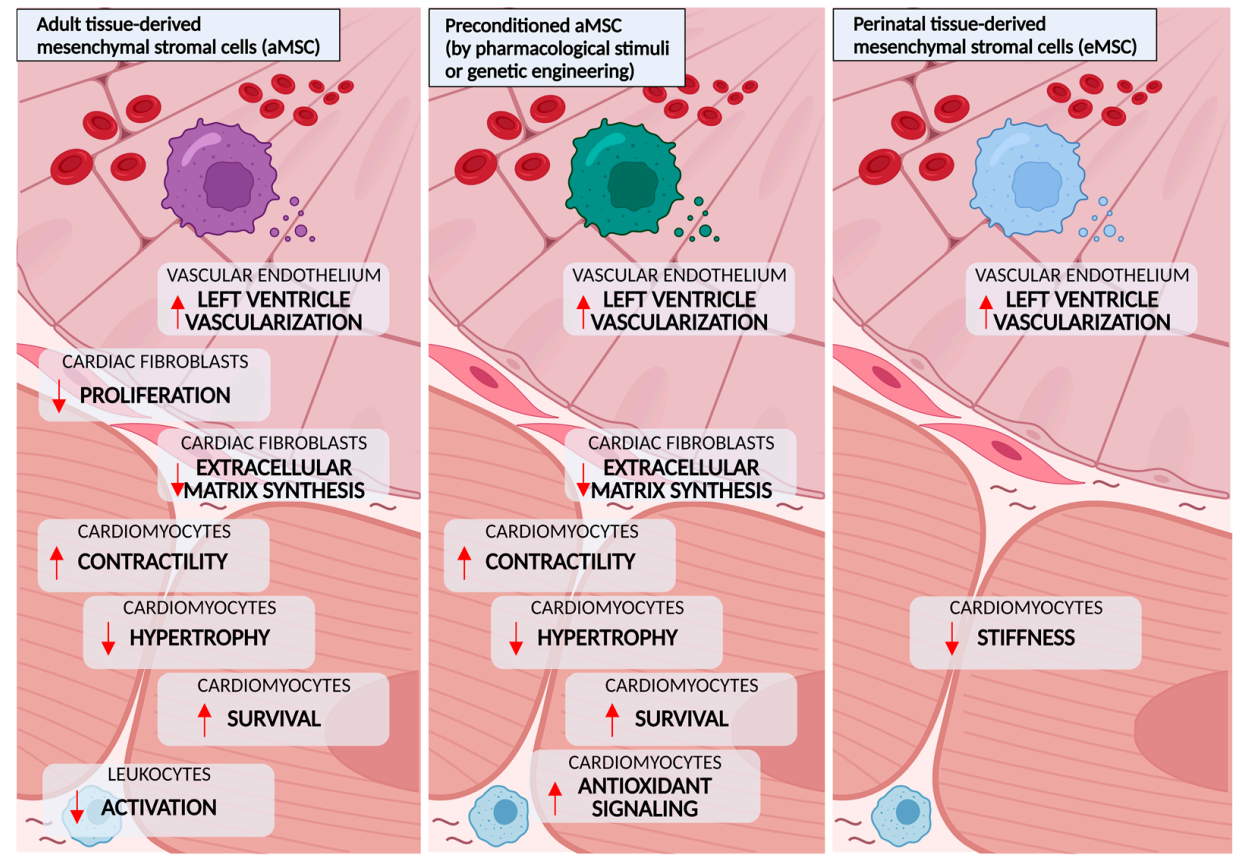

Figure 2. Beneficial effects of mesenchymal stromal cells (MSCs) observed in preclinical models of diabetes. Extracellular vesicle secretion by MSCs derived from adult (bone marrow, adipose tissue) or embryonic tissue-derived (placenta) restores endothelial and cardiomyocyte functions, reverting cardiac hypertrophy and the reduced contractility observed in diabetic animals. In addition to this, by lowering the activation of inflammatory cells and fibroblasts, MSCs reduce myocyte apoptosis and the fibrotic remodeling seen in rodent models. 


\subsection{Adult Tissue-Derived MSCs}

Most preclinical studies regarding MSCs as therapeutic agents for DCM use MSCs isolated from bone marrow (BM-MSCs). In one of the first reports, a single intravenous injection of $5 \times 10^{6}$ BM-MSCs attenuated cardiac fibrotic remodeling and induced angiogenesis in streptozotocin (STZ)-induced diabetic rats [106]. BM-MSCs transplantation induced a significant improvement in several cardiac parameters in relation to the control group, such as left ventricular posterior wall thickness, fractional shortening (FS) and relative wall thickness. BM-MSCs therapy induced a reduction in cardiac fibrosis, an effect possibly induced by the modulation of metalloproteinase expression and activity. The increased arteriolar density in myocardium from BM-MSCs-treated groups indicated an increase in angiogenesis. The presence of transplanted cells in the myocardium 4 weeks after the injections, as well as co-localization with cardiac markers (such as troponin T), suggested that part of BM-MSCs' beneficial effects might be due to their differentiation in cardiomyocytes [106]. In a model of obesity-induced DCM in mice, cardiac dysfunction is only detectable after a pharmacological stress (stimulation with dobutamine, a sympathomimetic drug); however, intravenous administration of BM-MSCs had no effect on cardiac function [107]. Other mechanisms of BM-MSCs' positive effects in DCM have been proposed and investigated in recent years. Serial intravenous injections of $5 \times 10^{5}$ BM-MSCs, once a week for four weeks, in addition to improving cardiac function as described above, have been shown to reduce the expression of the apoptotic protein caspase- 3 in DCM rats myocardium, while levels of 14-3-3 and phospho-Ask1, proteins with anti-apoptotic activity, were increased by therapy [108]. Most of the effects induced by MSCs are due to their paracrine action, and MSCs-derived extracellular vesicles, which include microvesicles and exosomes, are in focus as a cell-free therapeutic alternative. BM-MSCs exosomes injected intravenously once a week for 12 consecutive weeks in diabetic rats significantly reduced left ventricular collagen levels, an important indicator of cardiac fibrosis. Transforming growth factor-beta (TGF- $\beta$ )/Smad2 is one of the major signaling pathways related to cardiac fibrosis, and mRNA levels were upregulated in the myocardium of diabetic rats, and this effect was partially reverted by exosome therapy [109].

When considering a possible translation to clinical practice, it is important to evaluate the interactions between MSCs transplantation and the standard diabetes therapeutic strategies. In a recent work, Ammar and colleagues investigated the effects of BM-MSCs therapy in STZ rats that were also treated with metformin [110], currently the most used antidiabetic drug. Metformin reduced the cardioprotective effects and glucose control induced by intravenous BM-MSCs therapy. According to others, BM-MSCs therapy significantly reduced collagen deposition in the myocardium of STZ rats to levels similar to those of non-diabetic animals, but this effect was attenuated when also treated orally with metformin. BM-MSCs induced an increase in myocardium microvessel number, indicating an angiogenic effect, which was diminished but not abolished by metformin supplementation. The reduction in the beneficial effects of BM-MSCs therapy by metformin are probably related to the reduced homing and engraftment capacity of BM-MSCs in the myocardium caused by the drug [110]. Another important aspect considering clinical translation is the characterization and homogeneity of cell products. Recently, the effects of syndecan-2 $2^{+}$BM-MSCs have been analyzed in early pre-fibrotic DCM in $\mathrm{db} / \mathrm{db}$ transgenic mice. Syndecan-2 is a heparan sulfate proteoglycan and is considered a potential functional marker for the isolation of an MSC subpopulation. Although syndecan-2+ BM-MSCs, syndecan-2- BM-MSCs and wild-type BM-MSCs induced a reduction in cardiomyocyte stiffness and an increase in arteriole density, the effects were slightly less pronounced in the syndecan-2 $2^{+}$BM-MSC group [111].

In recent years, adipose tissue has been the most frequently used source of MSCs for clinical application because it provides not only a greater amount of cells compared to bone marrow but also allows autologous transplantation [112]. Recently, adipose tissue-derived MSCs (AT-MSCs) have been tested for the treatment of STZ-induced DCM in rats. Intravenous injection of allogeneic AT-MSCs reduced myocardial inflammation by promoting 
M2 macrophage polarization and reversing the elevation of the pro-inflammatory cytokines IL- 6 and TNF- $\alpha$ in heart tissue. This strategy also ameliorated fibrosis by suppressing the proliferation of cardiac fibroblasts, reducing TGF- $\beta$ expression and collagen deposition, preventing ventricular hypertrophy and diastolic dysfunction [113]. Pretreatment with cyclooxygenase- 2 inhibitor or the genetic deletion of prostaglandin E2 synthase abolished the cardioprotective effects, indicating the involvement of prostaglandin secretion [114]. Intravenous autologous AT-MSCs transplantation reduces fibrosis and cell death in cardiac tissue by increasing the expression of survival signaling molecules and reducing hypertrophic markers levels, which results in improved cardiac function [115]. Recently, it was demonstrated that AT-MSCs might prevent DCM by downregulating the adhesion of macrophages in heart tissue and by inhibiting autophagy-related apoptosis of myocardial cells [116].

\subsection{Preconditioning and Genetic Modification of Adult Tissue-Derived MSCs}

Although in preclinical studies, BM-MSCs and AT-MSCs are usually isolated from young and healthy donors, in clinical practice, cell therapy is generally autologous, which means that cells are harvested from the patient a few weeks prior to transplantation, reducing the immunological rejection risk and related complications. However, DM can markedly alter the biological properties of endogenous MSCs $[117,118]$. Diabetic BMMSCs have normal morphology but decreased proliferation rates and secrete less vascular endothelial growth factor (VEGF) and insulin-like growth factor-1 (IGF-1), cytokines related to angiogenesis and apoptosis inhibition, when compared to BM-MSCs from healthy donors. Moreover, diabetic BM-MSCs are more susceptible to apoptosis induced by hypoxia and serum deprivation and have impaired in vitro myogenic differentiation capacity [119]. However, some alterations seen in diabetic MSCs can be reverted using myogenic medium preconditioning. The preconditioning of BM-MSCs can improve their proliferative rate and the production of cardioprotective and angiogenic factors. This condition can also provide an increase in cardiac homing and a reduction in cardiac dysfunction and remodeling [117].

As previously mentioned, interesting approaches to increase MSCs' therapeutic effects are preconditioning, changing culture conditions and genetically modifying cells in vitro prior to transplantation. BM-MSCs cultivated in anoxic conditions for 3h (AP-MSCs) prior to direct transplantation in the myocardium induced more expressive positive effects in diabetic rats than control BM-MSCs. AP-MSCs induced a greater improvement in heart hypertrophy and FS in relation to BM-MSCs kept in standard conditions. AP-MSCs also increased capillary density in the myocardium [120]. Improvement in stem cell survival and therapeutic potential was detected after intravenous administration of $1 \times 10^{6} \mathrm{BM}-\mathrm{MSC}$ combined with resveratrol (RSV-BM-MSCs) in diabetic rats. RSV has been associated with cardioprotective effects in DCM preclinical models [121], and RSV increased the proliferation rate and antioxidant properties of BM-MSCs. In vivo, long-term treatment with systemic RSV improved lipid profile, thereby reducing triglycerides levels. This was also observed in animals that received RSV-BM-MSCs but not in those submitted to cell therapy alone. Interestingly, animals treated with RSV-BM-MSCs presented better cardioprotective effects because echocardiography indicated that the values of ejection fraction (EF) and FS were similar to those of non-diabetic rats. Moreover, it reduced cardiac fibrosis and cardiomyocytes hypertrophy [122].

The previously described beneficial effects obtained with AT-MSC therapy were even greater when preconditioned with resveratrol, which increased cell viability, migration and secretory capacity by upregulating the expression of CXCR4 and proteins related to the antioxidant Sirt 1/Akt axis. They have also shown that the beneficial effects of cell therapy with AT-MSCs were potentiated by the oral administration of green tea epigallocatechin-3-gallate, which has great antioxidant potential [123].

Recently, BM-MSCs modified to express adiponectin (APN-BM-MSCs) were evaluated in heart fibrosis attenuation in rats submitted to a high-fat diet associated with STZ injection. APN is usually secreted by adipocytes and has been related to a reduction in 
insulin-resistance and anti-atherosclerotic effects. Intravenous injection of $4 \times 10^{6} \mathrm{APN}-$ BM-MSCs attenuated cardiac hypertrophy seen in diabetic rats, an effect not obtained with non-modified BM-MSC therapy. Echocardiograms demonstrated an improvement in left ventricular ejection fraction (LVEF) in animals treated with non-modified BM-MSCs, but other cardiac function parameters, such as fractional shortening (FS) and left ventricular internal diameter end systole (LVID), were only improved in rats that received APN-BMMSCs. Regarding myocardium tissue morphology, APN-BM-MSC therapy reduced fibrotic area and collagen deposition. TGF- $\beta$ )/Smad2/3, which was upregulated in diabetic hearts, was prevented in animals submitted to APN-BM-MSC therapy [124].

\subsection{Perinatal Tissue-Derived MSCs}

MSCs derived from birth-associated tissues represent a good alternative for allogeneic transplantation. In addition to the previously mentioned advantages in obtaining these types of cells, they display improved features over adult MSCs in terms of proliferation, life span and epigenetic modifications [125]. Intravenous injection of placental-derived MSC-like cells, termed PLX, improved diastolic function at an early stage of DCM in STZ-induced diabetic mice by improving left ventricle vascularization and reducing cardiomyocyte stiffness before the onset of myocardial inflammation and fibrosis [126]. Table 1 summarizes the main findings of MSC therapy in relation to cardiac structure and function in preclinical models of DM.

Table 1. Summary of findings from preclinical studies.

\begin{tabular}{|c|c|c|c|c|}
\hline Agent/Cells & Preconditioning & Model & Effect and/or Mechanism & Ref. \\
\hline BM-MSCs & - & STZ rats & $\begin{array}{l}\downarrow \text { Cardiac hypertrophy (LV posterior wall } \\
\text { thickness and relative wall thickness); } \\
\uparrow \text { Myocardial arteriole density; } \\
\uparrow \text { LV systolic function and FS; } \\
\downarrow \text { LV collagen content; } \\
\downarrow \text { Cardiac expression of MMP-9; }\end{array}$ & [106] \\
\hline BM-MSCs & - & HF diet mice & $\begin{array}{l}\uparrow / \downarrow \text { Cardiac contractility }(+\mathrm{dP} / \mathrm{dt}) \text { and } \\
\text { relaxation }(-\mathrm{dP} / \mathrm{dt}) \text {; }\end{array}$ & [107] \\
\hline BM-MSCs & - & $\mathrm{STZ}+\mathrm{HF} / \mathrm{HS}$ diet rats & $\begin{array}{l}\downarrow \text { Cardiac expression of caspase- } 3 \text {; } \\
\uparrow \text { Cardiac expression of } 14-3-3, \text { p-Ask } 1\end{array}$ & [108] \\
\hline BM-MSCs & - & STZ rats treated with RSV & $\begin{array}{l}\downarrow \text { Cardiac apoptosis (Bax/Bcl2 ratio); } \\
\downarrow \text { Cardiac expression of Wnt } 3 \text { and } \beta \text {-catenin; } \\
\downarrow \text { Cardiomyocyte hypertrophy; } \\
\uparrow \text { Myocardial capillary density; } \\
\uparrow \text { Cardiac antioxidant defenses (TAC, SOD); } \\
\text { Attenuated reduction in blood glucose; }\end{array}$ & [122] \\
\hline BM-MSCs & - & STZ rats treated with MET & $\begin{array}{l}\text { Attenuated cardiac angiogenesis; } \\
\text { Attenuated reduction in LV collagen content; } \\
\downarrow \text { LV wall thinning and dilation; } \\
\downarrow \text { Diastolic dysfunction; }\end{array}$ & [110] \\
\hline AT-MSCs & - & STZ rats & $\begin{array}{l}\downarrow \text { Cardiac collagen content and fibrosis; } \\
\downarrow \text { Proliferation of cardiac fibroblasts; } \\
\downarrow \text { Cardiac expression of IL- } 6 \text {, TNF- } \alpha \text {, TGF- } \beta \text {; } \\
\uparrow \text { Macrophage polarization to M2 phenotype; }\end{array}$ & [113] \\
\hline AT-MSCs & - & STZ+HF diet mice & $\begin{array}{l}\downarrow \text { Blood glucose and cholesterol; } \\
\uparrow \text { LV systolic function (FS and EF); } \\
\downarrow \text { Cardiomyocyte hypertrophy; } \\
\downarrow \text { Cardiac collagen content; } \\
\downarrow \text { Cardiac macrophage number; } \\
\downarrow \text { Cardiac TNF, CXCL15, IL6 mRNA levels; } \\
\downarrow \text { Cardiac expression of IL-1 } \beta ;\end{array}$ & [116] \\
\hline
\end{tabular}


Table 1. Cont.

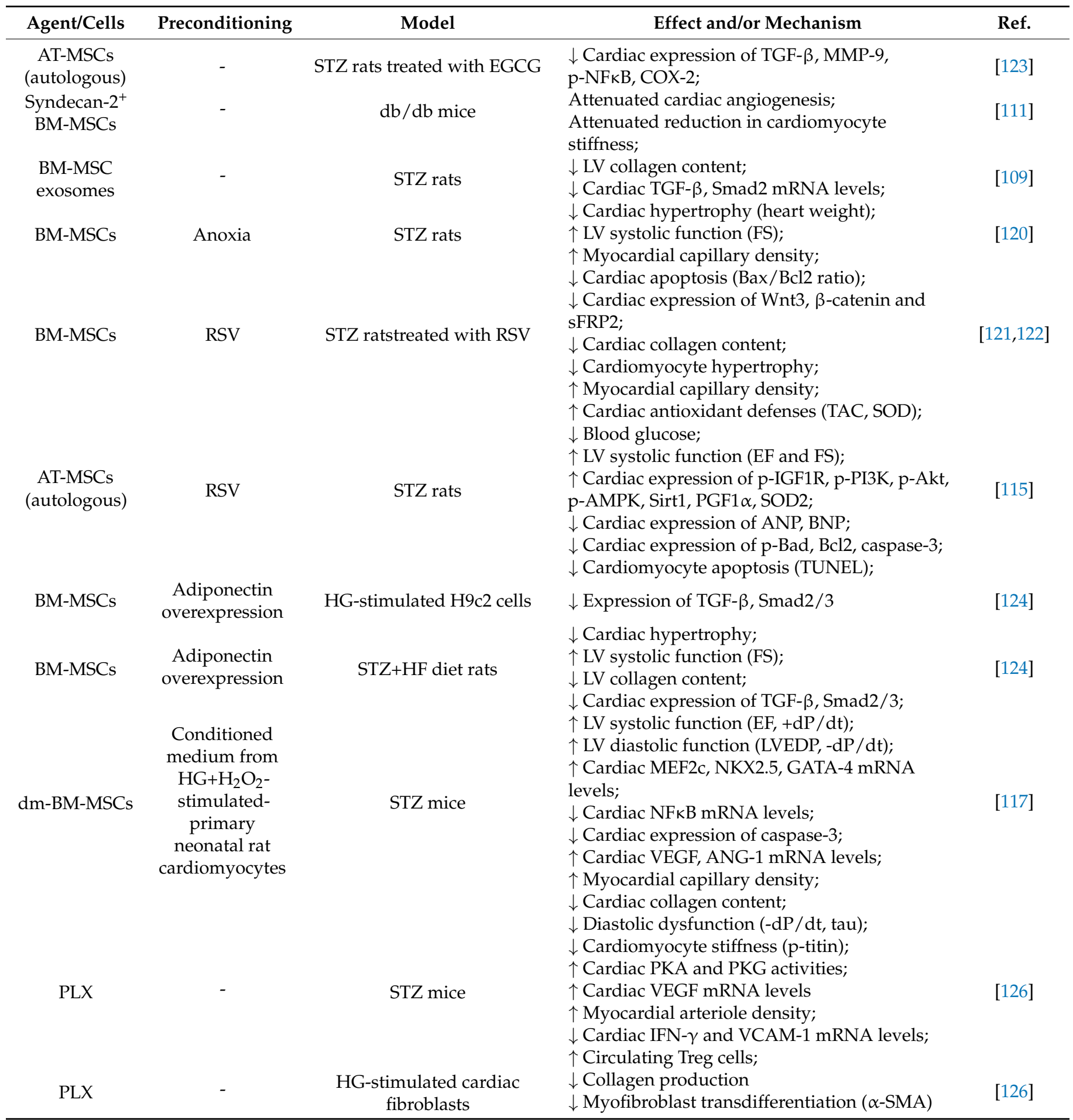

$\uparrow$, increased; $\downarrow$, reduced; ANG-1, angiopoietin-1; AT-MSCs, adipose tissue-derived MSCs; BM-MSCs, bone marrow-derived MSCs; DCM, diabetic cardiomyopathy; dm-BM-MSCs, diabetic mouse-derived BM-MSCs; EF, ejection fraction; EGCG, epigallocatechin-3-gallate; FS, fractional shortening; HF, high fat; HG, high glucose; HS, high sugar; IFN- $\gamma$, interferon- $\gamma$; IL-6, interleukin-6; IPCs, insulin-producing cells; LV, left ventricle; MEF2c, myocyte-specific enhancer factor; MET, metformin; MMP-9, matrix metalloproteinase-9; MSCs, mesenchymal stromal cells; $\mathrm{NF \kappa B}$, nuclear factor $\mathrm{kB}$; PKA, protein kinase A; PKG, protein kinase G; PLX, placenta-derived MSClike cells; RSV, resveratrol; RSV-BM-MSCs, BM-MSCs combined with resveratrol; sFRP2, secreted frizzled-related protein; $\alpha$-SMA, $\alpha$-smooth muscle actin; SOD, superoxide dismutase; STZ, streptozotocin; TAC, total antioxidant capacity; TGF- $\beta$, transforming growth factor- $\beta$; TNF- $\alpha$, tumor necrosis factor- $\alpha$; VCAM- 1 , vascular cell adhesion molecule-1; VEGF, vascular endothelial growth factor. 


\subsection{Clinical Studies}

DCM is usually an asymptomatic disease in the early stages and is often accompanied by other complications induced by DM, making an accurate diagnosis and even the selection of patients for clinical trials difficult. Indeed, many of the DCM-related studies registered on clinicaltrials.gov (accessed on 21 December 2021) look for early, specific and effective diagnostic methods (NCT04593173, NCT04534894, NCT01295385, NCT01220349 and NCT04303364). To date, there are no clinical trials testing the efficacy of MSC-based therapy in the treatment of DCM specifically. However, there are several studies that include patients with ischemic and non-ischemic cardiomyopathies with DM as a comorbidity, most of them using BM-MSCs transplanted by transendocardial injection, although intravenous and intracoronary infusion have also been tested $[127,128]$. The majority have focused on the impact of cell therapy on ischemic cardiomyopathy, but a comparative analysis indicated that cardiac function improved preferentially in non-ischemic cardiomyopathy [129], with higher clinically significant efficacy for allogeneic than for autologous cells $[130,131]$.

In general, cell therapy is safe and feasible for treating cardiomyopathy, with no serious adverse events and recovered parameters of systolic and diastolic functions and functional capacity, improving patients' quality of life. Therapeutic responses are not impaired by gender or age [132,133]; however, possible differences between diabetic and non-diabetic patients have not been described. Furthermore, several studies have shown that the clinical application of MSC transplantation in DM type 1 and type 2 has positive metabolic effects, regulating hyperglycemia and insulin resistance [134], which are the key determinants for DCM pathogenesis.

Therefore, evidence points to MSCs as a powerful tool for the treatment of DCM, but larger studies are warranted to determine the ideal cell source, as well as the best route of administration and timing of transplantation, and to confirm the benefits observed in preclinical studies.

\section{Conclusions}

MSCs attenuate cardiac remodeling induced by DM, reducing cardiac fibrosis and improving systolic and diastolic function; thus, MSCs are a promising therapeutic strategy for the prevention of DCM. However, although some clinical trials have shown improvement in cardiac function and quality of life in patients with ischemic and non-ischemic cardiomyopathy, as well as its favorable metabolic effects for patients with DM, it is still necessary to expand the research concerning the effects of MSCs on improving cardiac remodeling and preventing DCM. The lack of an early and accurate DCM diagnosis contributes to the main challenge in the research and development of preventive and effective cell therapy. Despite the promising results found in preclinical studies, animal models are not representative of how the disease appears in diabetic patients, who feature hypertension, coronary artery disease or other cardiovascular disorders. Regarding the therapeutic potential of MSCs, a key point is to identify and optimize the ideal cell source in terms of harvesting, cultivation, expansion, safety and efficacy. DM interferes with MSCs' properties, amount and function; thus, the preconditioning and genetic manipulation or delivering strategies are recommended to improve their survival and therapeutic efficacy when considering autologous transplantation. Transendocardial delivery of MSCs has been shown to be feasible, safe and beneficial in patients with different types of cardiomyopathies, but further trials with a larger number of patients and a longer follow-up are imperative to assess the long-lasting effects. Furthermore, knowledge of the interference of MSCs and their secreted substances on the signaling pathways is crucial to use their regenerative effect to prevent cardiac remodeling of DCM. Therefore, despite being a highly promising tool for the treatment of DCM, the standardization, quality and consistency of MSC-based therapy still require extensive future research. 


\begin{abstract}
Author Contributions: Drafted manuscript, J.S.d.S., R.G.J.G., J.F.V., M.P.L.d.S., R.M.-O., B.S.R., B.N.-C., T.L.M. and G.Z.-S.; prepared figures, T.L.M.; edited and revised manuscript, J.S.d.S., R.G.J.G., J.F.V., B.S.R., B.N.-C., T.L.M. and G.Z.-S. All authors have read and agreed to the published version of the manuscript.
\end{abstract}

Funding: This research was funded by Conselho Nacional de Desenvolvimento Científico e Tecnológico (CNPq) -Proc. 428102/2018-2; Fundação de Amparo à Pesquisa do Estado do Rio de Janeiro (FAPERJ)—E-26/200.881/2021. And The APC was funded by FAPERJ E-26/200.881/2021.

\begin{abstract}
Acknowledgments: Coordenação de Aperfeiçoamento de Pessoal de Nível Superior (CAPES), Conselho Nacional de Desenvolvimento Científico e Tecnológico (CNPq), Fundação de Amparo à Pesquisa do Estado do Rio de Janeiro (FAPERJ). Figures created with BioRender.com (Figure 1, license agreement JQ2361Q60S for T.L.M.; Figure 2, license agreement DO23CQ4L5E for T.L.M.).
\end{abstract}

Conflicts of Interest: The authors declare no conflict of interest.

\title{
References
}

1. Sinclair, A.; Saeedi, P.; Kaundal, A.; Karuranga, S.; Malanda, B.; Williams, R. Diabetes and global ageing among 65-99-year-old adults: Findings from the International Diabetes Federation Diabetes Atlas, 9th edition. Diabetes Res. Clin. Pract. 2020, 162, 108078. [CrossRef]

2. Saeedi, P.; Petersohn, I.; Salpea, P.; Malanda, B.; Karuranga, S.; Unwin, N.; Colagiuri, S.; Guariguata, L.; Motala, A.A.; Ogurtsova, K.; et al. Global and regional diabetes prevalence estimates for 2019 and projections for 2030 and 2045: Results from the International Diabetes Federation Diabetes Atlas, 9th edition. Diabetes Res. Clin. Pract. 2019, 157, 107843. [CrossRef] [PubMed]

3. Kaur, R.; Kaur, M.; Singh, J. Endothelial dysfunction and platelet hyperactivity in type 2 diabetes mellitus: Molecular insights and therapeutic strategies. Cardiovasc. Diabetol. 2018, 17, 121. [CrossRef] [PubMed]

4. $\quad$ El Hayek, M.S.; Ernande, L.; Benitah, J.-P.; Gomez, A.-M.; Pereira, L. The role of hyperglycaemia in the development of diabetic cardiomyopathy. Arch. Cardiovasc. Dis. 2021, 114, 748-760. [CrossRef]

5. Azevedo, P.S.; Polegato, B.F.; Minicucci, M.F.; Paiva, S.A.R.; Zornoff, L.A.M. Cardiac Remodeling: Concepts, Clinical Impact, Pathophysiological Mechanisms and Pharmacologic Treatment. Arq. Bras. Cardiol. 2016, 106, 62-69. [CrossRef] [PubMed]

6. Chen, W.; Ju, J.; Yang, Y.; Wang, H.; Chen, W.; Zhao, X.; Ye, H.; Zhang, Y. Astragalus polysaccharides protect cardiac stem and progenitor cells by the inhibition of oxidative stress-mediated apoptosis in diabetic hearts. Drug Des. Dev. Ther. 2018, 12, 943-954. [CrossRef] [PubMed]

7. Yang, F.; Yu, X.; Li, T.; Wu, J.; Zhao, Y.; Liu, J.; Sun, A.; Dong, S.; Wu, J.; Zhong, X.; et al. Exogenous $\mathrm{H}_{2} \mathrm{~S}$ regulates endoplasmic reticulum-mitochondria cross-talk to inhibit apoptotic pathways in STZ-induced type I diabetes. Am. J. Physiol. Endocrinol. Metab. 2017, 312, E190-E203. [CrossRef] [PubMed]

8. Lin, C.; Guo, Y.; Xia, Y.; Li, C.; Xu, X.; Qi, T.; Zhang, F.; Fan, M.; Hu, G.; Zhao, H.; et al. FNDC5/Irisin attenuates diabetic cardiomyopathy in a type 2 diabetes mouse model by activation of integrin $\alpha \mathrm{V} / \beta 5$-AKT signaling and reduction of oxidative/nitrosative stress. J. Mol. Cell. Cardiol. 2021, 160, 27-41. [CrossRef] [PubMed]

9. Tavares, A.M.; Silva, J.H.; de Oliveira Bensusan, C.; Ferreira, A.C.F.; de Lima Matos, L.P.; de Araujo e Souza, K.L.; de Carvalho Cardoso-Weide, L.; Taboada, G.F. Altered superoxide dismutase-1 activity and intercellular adhesion molecule 1 (ICAM-1) levels in patients with type 2 diabetes mellitus. PLOS ONE 2019, 14, e0216256. [CrossRef]

10. Papanas, N.; Tziakas, D.; Chalikias, G.; Floros, D.; Trypsianis, G.; Papadopoulou, E.; Kortsaris, A.; Symeonidis, G.; Souliou, E.; Maltezos, E.; et al. Gliclazide treatment lowers serum ICAM-1 levels in poorly controlled type 2 diabetic patients. Diabetes Metab. 2006, 32, 344-349. [CrossRef]

11. Chen, F.; Song, J. Cardioprotective Action of Glycyrrhizin on Diabetic Rats with Myocardial Remodeling. J. Healthc. Eng. 2021, 2021, 6343677. [CrossRef] [PubMed]

12. Mishra, V.; Nayak, P.; Sharma, M.; Albutti, A.; Alwashmi, A.S.S.; Aljasir, M.A.; Alsowayeh, N.; Tambuwala, M.M. Emerging Treatment Strategies for Diabetes Mellitus and Associated Complications: An Update. Pharmaceutics 2021, 13, 1568. [CrossRef] [PubMed]

13. Naji, A.; Eitoku, M.; Favier, B.; Deschaseaux, F.; Rouas-Freiss, N.; Suganuma, N. Biological functions of mesenchymal stem cells and clinical implications. Cell. Mol. Life Sci. 2019, 76, 3323-3348. [CrossRef] [PubMed]

14. Ocansey, D.K.W.; Pei, B.; Yan, Y.; Qian, H.; Zhang, X.; Xu, W.; Mao, F. Improved therapeutics of modified mesenchymal stem cells: An update. J. Transl. Med. 2020, 18, 42. [CrossRef] [PubMed]

15. Tan, Y.; Zhang, Z.; Zheng, C.; Wintergerst, K.A.; Keller, B.B.; Cai, L. Mechanisms of diabetic cardiomyopathy and potential therapeutic strategies: Preclinical and clinical evidence. Nat. Rev. Cardiol. 2020, 17, 585-607. [CrossRef] [PubMed]

16. Li, K.; Zhai, M.; Jiang, L.; Song, F.; Zhang, B.; Li, J.; Li, H.; Li, B.; Xia, L.; Xu, L.; et al. Tetrahydrocurcumin Ameliorates Diabetic Cardiomyopathy by Attenuating High Glucose-Induced Oxidative Stress and Fibrosis via Activating the SIRT1 Pathway. Oxid. Med. Cell. Longev. 2019, 2019, 6746907. [CrossRef]

17. Li, L.; Zhao, Q.; Kong, W. Extracellular matrix remodeling and cardiac fibrosis. Matrix Biol. 2018, 68-69, 490-506. [CrossRef]

18. Jia, G.; Hill, M.A.; Sowers, J.R. Diabetic Cardiomyopathy: An Update of Mechanisms Contributing to This Clinical Entity. Circ. Res. 2018, 122, 624-638. [CrossRef] 
19. Ren, J.; Bi, Y.; Sowers, J.R.; Hetz, C.; Zhang, Y. Endoplasmic reticulum stress and unfolded protein response in cardiovascular diseases. Nat. Rev. Cardiol. 2021, 18, 499-521. [CrossRef]

20. Tao, A.; Song, J.; Lan, T.; Xu, X.; Kvietys, P.; Kao, R.; Martin, C.; Rui, T. Cardiomyocyte-fibroblast interaction contributes to diabetic cardiomyopathy in mice: Role of HMGB1/TLR4/IL-33 axis. Biochim. Biophys. Acta 2015, 1852, 2075-2085. [CrossRef]

21. Dozio, E.; Massaccesi, L.; Corsi Romanelli, M.M. Glycation and Glycosylation in Cardiovascular Remodeling: Focus on Advanced Glycation End Products and O-Linked Glycosylations as Glucose-Related Pathogenetic Factors and Disease Markers. J. Clin. Med. 2021, 10, 4792. [CrossRef] [PubMed]

22. Russo, I.; Frangogiannis, N.G. Diabetes-associated cardiac fibrosis: Cellular effectors, molecular mechanisms and therapeutic opportunities. J. Mol. Cell. Cardiol. 2016, 90, 84-93. [CrossRef] [PubMed]

23. Katare, R.; Oikawa, A.; Cesselli, D.; Beltrami, A.P.; Avolio, E.; Muthukrishnan, D.; Munasinghe, P.E.; Angelini, G.; Emanueli, C.; Madeddu, P. Boosting the pentose phosphate pathway restores cardiac progenitor cell availability in diabetes. Cardiovasc. Res. 2013, 97, 55-65. [CrossRef] [PubMed]

24. Leonardini, A.; Avogaro, A. Abnormalities of the cardiac stem and progenitor cell compartment in experimental and human diabetes. Arch. Physiol. Biochem. 2013, 119, 179-187. [CrossRef]

25. Feng, W.; Lei, T.; Wang, Y.; Feng, R.; Yuan, J.; Shen, X.; Wu, Y.; Gao, J.; Ding, W.; Lu, Z. GCN2 deficiency ameliorates cardiac dysfunction in diabetic mice by reducing lipotoxicity and oxidative stress. Free Radic. Biol. Med. 2019, 130, 128-139. [CrossRef]

26. Li, C.; Zhang, J.; Xue, M.; Li, X.; Han, F.; Liu, X.; Xu, L.; Lu, Y.; Cheng, Y.; Li, T.; et al. SGLT2 inhibition with empagliflozin attenuates myocardial oxidative stress and fibrosis in diabetic mice heart. Cardiovasc. Diabetol. 2019, 18, 15. [CrossRef]

27. Zhu, H.Z.; Zhang, L.Y.; Zhai, M.E.; Xia, L.; Cao, Y.; Xu, L.; Li, K.F.; Jiang, L.Q.; Shi, H.; Li, X.; et al. GDF11 Alleviates Pathological Myocardial Remodeling in Diabetic Cardiomyopathy Through SIRT1-Dependent Regulation of Oxidative Stress and Apoptosis. Front. Cell Dev. Biol. 2021, 9, 686848. [CrossRef]

28. Bindu, S.; Pillai, V.B.; Gupta, M.P. Role of Sirtuins in Regulating Pathophysiology of the Heart. Trends Endocrinol. Metab. 2016, 27, 563-573. [CrossRef]

29. Han, Y.; Sun, W.; Ren, D.; Zhang, J.; He, Z.; Fedorova, J.; Sun, X.; Han, F.; Li, J. SIRT1 agonism modulates cardiac NLRP3 inflammasome through pyruvate dehydrogenase during ischemia and reperfusion. Redox Biol. 2020, 34, 101538. [CrossRef]

30. Ren, B.; Zhang, Y.; Liu, S.; Cheng, X.; Yang, X.; Cui, X.; Zhao, X.; Zhao, H.; Hao, M.; Li, M.; et al. Curcumin alleviates oxidative stress and inhibits apoptosis in diabetic cardiomyopathy via Sirt1-Foxo1 and PI3K-Akt signalling pathways. J. Cell. Mol. Med. 2020, 24, 12355-12367. [CrossRef]

31. Waldman, M.; Nudelman, V.; Shainberg, A.; Zemel, R.; Kornwoski, R.; Aravot, D.; Peterson, S.J.; Arad, M.; Hochhauser, E. The Role of Heme Oxygenase 1 in the Protective Effect of Caloric Restriction against Diabetic Cardiomyopathy. Int. J. Mol. Sci. 2019, 20, 2427. [CrossRef]

32. Liu, J.-J.; Wong, M.D.S.; Toy, W.C.; Tan, C.S.H.; Liu, S.; Ng, X.W.; Tavintharan, S.; Sum, C.F.; Lim, S.C. Lower circulating irisin is associated with type 2 diabetes mellitus. J. Diabetes Complicat. 2013, 27, 365-369. [CrossRef]

33. Shen, C.-Y.; Lu, C.-H.; Wu, C.-H.; Li, K.-J.; Kuo, Y.-M.; Hsieh, S.-C.; Yu, C.-L. The Development of Maillard Reaction, and Advanced Glycation End Product (AGE)-Receptor for AGE (RAGE) Signaling Inhibitors as Novel Therapeutic Strategies for Patients with AGE-Related Diseases. Molecules 2020, 25, 5591. [CrossRef]

34. Zhao, J.; Randive, R.; Stewart, J.A. Molecular mechanisms of AGE/RAGE-mediated fibrosis in the diabetic heart. World J. Diabetes 2014, 5, 860-867. [CrossRef] [PubMed]

35. Bansode, S.B.; Gacche, R.N. Glycation-induced modification of tissue-specific ECM proteins: A pathophysiological mechanism in degenerative diseases. Biochim. Biophys. Acta Gen. Subj. 2019, 1863, 129411. [CrossRef] [PubMed]

36. Monroe, T.B.; Anderson, E.J. A Catecholaldehyde Metabolite of Norepinephrine Induces Myo fi broblast Activation and Toxicity via the Receptor for Advanced Glycation Endproducts: Mitigating Role of 1-Carnosine. Chem. Res. Toxicol. 2021, 34, $2194-2201$. [CrossRef]

37. Fowlkes, V.; Clark, J.; Fix, C.; Law, B.A.; Morales, M.O.; Qiao, X.; Ako-Asare, K.; Goldsmith, J.G.; Carver, W.; Murray, D.B.; et al Type II diabetes promotes a myofibroblast phenotype in cardiac fibroblasts. Life Sci. 2013, 92, 669-676. [CrossRef] [PubMed]

38. Burr, S.D.; Stewart, J.A. Extracellular matrix components isolated from diabetic mice alter cardiac fibroblast function through the AGE/RAGE signaling cascade. Life Sci. 2020, 250, 117569. [CrossRef] [PubMed]

39. Huang, S.; Wang, W.; Li, L.; Wang, T.; Zhao, Y.; Lin, Y.; Huang, W.; Wang, Y.; Huang, Z. P2X7 Receptor Deficiency Ameliorates STZ-induced Cardiac Damage and Remodeling through PKC $\beta$ and ERK. Front. Cell Dev. Biol. 2021, 9, 692028. [CrossRef]

40. Burnstock, G. Purinergic Signaling in the Cardiovascular System. Circ. Res. 2017, 120, 207-228. [CrossRef]

41. Sathanoori, R.; Swärd, K.; Olde, B.; Erlinge, D. The ATP Receptors P2X7 and P2X4 Modulate High Glucose and Palmitate-Induced Inflammatory Responses in Endothelial Cells. PLoS ONE 2015, 10, e0125111. [CrossRef]

42. Martinez, C.G.; Zamith-Miranda, D.; da Silva, M.G.; Ribeiro, K.C.; Brandão, I.T.; Silva, C.L.; Diaz, B.L.; Bellio, M.; Persechini, P.M.; Kurtenbach, E. P2 $\times 7$ purinergic signaling in dilated cardiomyopathy induced by auto-immunity against muscarinic M2 receptors: Autoantibody levels, heart functionality and cytokine expression. Sci. Rep. 2015, 5, srep16940. [CrossRef]

43. Wenzl, F.A.; Ambrosini, S.; Mohammed, S.A.; Kraler, S.; Lüscher, T.F.; Costantino, S.; Paneni, F. Inflammation in Metabolic Cardiomyopathy. Front. Cardiovasc. Med. 2021, 8, 742178. [CrossRef] [PubMed]

44. Mishra, S.; Kass, D.A. Cellular and molecular pathobiology of heart failure with preserved ejection fraction. Nat. Rev. Cardiol. 2021, 18, 400-423. [CrossRef] [PubMed] 
45. Nishida, K.; Otsu, K. Inflammation and metabolic cardiomyopathy. Cardiovasc. Res. 2017, 113, 389-398. [CrossRef] [PubMed]

46. Frati, G.; Schirone, L.; Chimenti, I.; Yee, D.; Biondi-Zoccai, G.; Volpe, M.; Sciarretta, S. An overview of the inflammatory signalling mechanisms in the myocardium underlying the development of diabetic cardiomyopathy. Cardiovasc. Res. 2017, 113, 378-388. [CrossRef]

47. Urbina, P.; Singla, D.K. BMP-7 attenuates adverse cardiac remodeling mediated through M2 macrophages in prediabetic cardiomyopathy. Am. J. Physiol. Heart Circ. Physiol. 2014, 307, H762-H772. [CrossRef]

48. Abd El Motteleb, D.M.; Abd El Aleem, D.I. Renoprotective effect of Hypericum perforatum against diabetic nephropathy in rats: Insights in the underlying mechanisms. Clin. Exp. Pharmacol. Physiol. 2017, 44, 509-521. [CrossRef]

49. Volz, H.C.; Kaya, Z.; Katus, H.A.; Andrassy, M. The role of HMGB1/RAGE in inflammatory cardiomyopathy. Semin. Thromb. Hemost. 2010, 36, 185-194. [CrossRef]

50. Jin, X.; Yao, T.; Zhou, Z.; Zhu, J.; Zhang, S.; Hu, W.; Shen, C. Advanced Glycation End Products Enhance Macrophages Polarization into M1 Phenotype through Activating RAGE/NF-кB Pathway. Biomed. Res. Int. 2015, 2015, 732450. [CrossRef]

51. Mouton, A.J.; Li, X.; Hall, M.E.; Hall, J.E. Obesity, Hypertension, and Cardiac Dysfunction: Novel Roles of Immunometabolism in Macrophage Activation and Inflammation. Circ. Res. 2020, 126, 789-806. [CrossRef] [PubMed]

52. Zayas, J.; Amaia, A.; Ainhoa, A.; De Yurre, R.; Echeazarra, L.; Fernández, V. Kv1. 3 Channel Blockade Improves Inflammatory Profile, Reduces Cardiac Electrical Remodeling, and Prevents Arrhythmia in Type 2 Diabetic Rats. Cardiovasc. Drugs Ther. 2021, 2021, 1-11. [CrossRef]

53. Zayas-Arrabal, J.; Alquiza, A.; Tuncay, E.; Turan, B.; Gallego, M.; Casis, O. Molecular and electrophysiological role of diabetesassociated circulating inflammatory factors in cardiac arrhythmia remodeling in a metabolic-induced model of type 2 diabetic rat Int. J. Mol. Sci. 2021, 22, 6827. [CrossRef] [PubMed]

54. Zhang, Q.; Liu, T.; Ng, C.Y.; Li, G. Diabetes Mellitus and Atrial Remodeling: Mechanisms and Potential Upstream Therapies. Cardiovasc. Ther. 2014, 32, 233-241. [CrossRef] [PubMed]

55. Xiao, L.; Dudley, A.C. Fine-tuning vascular fate during endothelial-mesenchymal transition. J. Pathol. 2017, 241, 25-35. [CrossRef]

56. Yue, Y.; Meng, K.; Pu, Y.; Zhang, X. Transforming growth factor beta (TGF- $\beta$ ) mediates cardiac fibrosis and induces diabetic cardiomyopathy. Diabetes Res. Clin. Pract. 2017, 133, 124-130. [CrossRef]

57. Kovacic, J.C. The Endothelial-Metabolic Axis: A Novel Cardiometabolic Disease Target. Trends Endocrinol. Metab. 2018, 29, 527-529. [CrossRef]

58. Okayama, K.; Azuma, J.; Dosaka, N.; Iekushi, K.; Sanada, F.; Kusunoki, H.; Iwabayashi, M.; Rakugi, H.; Taniyama, Y.; Morishita, R. Hepatocyte growth factor reduces cardiac fibrosis by inhibiting endothelial-mesenchymal transition. Hypertens 2012, 59, 958-965. [CrossRef]

59. Tian, J.; Zhang, M.; Suo, M.; Liu, D.; Wang, X.; Liu, M.; Pan, J.; Jin, T.; An, F. Dapagliflozin alleviates cardiac fibrosis through suppressing EndMT and fibroblast activation via AMPK $\alpha /$ TGF- $\beta /$ Smad signalling in type 2 diabetic rats. J. Cell. Mol. Med. 2021, 25, 7642-7659. [CrossRef]

60. Hu, X.; Bai, T.; Xu, Z.; Liu, Q.; Zheng, Y.; Cai, L. Pathophysiological Fundamentals of Diabetic Cardiomyopathy. Compr. Physiol. 2017, 7, 693-711. [CrossRef]

61. Salvatore, T.; Pafundi, P.C.; Galiero, R.; Albanese, G.; Di Martino, A.; Caturano, A.; Vetrano, E.; Rinaldi, L.; Sasso, F.C. The Diabetic Cardiomyopathy: The Contributing Pathophysiological Mechanisms. Front. Med. 2021, 8, 695792. [CrossRef] [PubMed]

62. Wang, J.; Wang, S.; Wang, J.; Xiao, M.; Guo, Y.; Tang, Y.; Zhang, J.; Gu, J. Epigenetic Regulation Associated with Sirtuin 1 in Complications of Diabetes Mellitus. Front. Endocrinol. (Lausanne) 2021, 11, 598012. [CrossRef] [PubMed]

63. Fernandez-Twinn, D.S.; Hjort, L.; Novakovic, B.; Ozanne, S.E.; Saffery, R. Intrauterine programming of obesity and type 2 diabetes. Diabetologia 2019, 62, 1789-1801. [CrossRef] [PubMed]

64. Mönkemann, H.; De Vriese, A.S.; Blom, H.J.; Kluijtmans, L.A.J.; Heil, S.G.; Schild, H.H.; Golubnitschaja, O. Early molecular events in the development of the diabetic cardiomyopathy. Amino Acids 2002, 23, 331-336. [CrossRef] [PubMed]

65. Tao, H.; Shi, P.; Xuan, H.-Y.; Ding, X.-S. DNA methyltransferase-1 inactivation of androgen receptor axis triggers homocysteine induced cardiac fibroblast autophagy in diabetic cardiac fibrosis. Arch. Biochem. Biophys. 2020, 692, 108521. [CrossRef] [PubMed]

66. Ghosh, A.K. p300 in Cardiac Development and Accelerated Cardiac Aging. Aging Dis. 2020, 11, 916. [CrossRef]

67. Bugyei-Twum, A.; Advani, A.; Advani, S.L.; Zhang, Y.; Thai, K.; Kelly, D.J.; Connelly, K.A. High glucose induces Smad activation via the transcriptional coregulator p300 and contributes to cardiac fibrosis and hypertrophy. Cardiovasc. Diabetol. 2014, 13, 89. [CrossRef]

68. Nicholls, S.J.; Schwartz, G.G.; Buhr, K.A.; Ginsberg, H.N.; Johansson, J.O.; Kalantar-Zadeh, K.; Kulikowski, E.; Toth, P.P.; Wong, N.; Sweeney, M.; et al. Apabetalone and hospitalization for heart failure in patients following an acute coronary syndrome: A prespecified analysis of the BETonMACE study. Cardiovasc. Diabetol. 2021, 20, 13. [CrossRef]

69. Kalantar-Zadeh, K.; Schwartz, G.G.; Nicholls, S.J.; Buhr, K.A.; Ginsberg, H.N.; Johansson, J.O.; Kulikowski, E.; Lebioda, K.; Toth, P.P.; Wong, N.; et al. Effect of Apabetalone on Cardiovascular Events in Diabetes, CKD, and Recent Acute Coronary Syndrome. Clin. J. Am. Soc. Nephrol. 2021, 16, 705-716. [CrossRef]

70. Mu, J.; Zhang, D.; Tian, Y.; Xie, Z.; Zou, M. BRD4 inhibition by JQ1 prevents high-fat diet-induced diabetic cardiomyopathy by activating PINK1/Parkin-mediated mitophagy in vivo. J. Mol. Cell. Cardiol. 2020, 149, 1-14. [CrossRef]

71. Wang, Q.; Sun, Y.; Li, T.; Liu, L.; Zhao, Y.; Li, L.; Zhang, L.; Meng, Y. Function of BRD4 in the pathogenesis of high glucose-induced cardiac hypertrophy. Mol. Med. Rep. 2018, 16, 705-716. [CrossRef] [PubMed] 
72. Palomer, X.; Román-Azcona, M.S.; Pizarro-Delgado, J.; Planavila, A.; Villarroya, F.; Valenzuela-Alcaraz, B.; Crispi, F.; Sepúlveda-Martínez, Á.; Miguel-Escalada, I.; Ferrer, J.; et al. SIRT3-mediated inhibition of FOS through histone H3 deacetylation prevents cardiac fibrosis and inflammation. Signal Transduct. Target. Ther. 2020, 5, 14. [CrossRef] [PubMed]

73. Ma, W.; Guo, W.; Shang, F.; Li, Y.; Li, W.; Liu, J.; Ma, C.; Teng, J. Bakuchiol Alleviates Hyperglycemia-Induced Diabetic Cardiomyopathy by Reducing Myocardial Oxidative Stress via Activating the SIRT1/Nrf2 Signaling Pathway. Oxid. Med. Cell. Longev. 2020, 2020, 3732718. [CrossRef] [PubMed]

74. Costantino, S.; Mohammed, S.A.; Ambrosini, S.; Paneni, F. Epigenetic processing in cardiometabolic disease. Atherosclerosis 2019, 281, 150-158. [CrossRef] [PubMed]

75. Yu, W.; Gao, B.; Li, N.; Wang, J.; Qiu, C.; Zhang, G.; Liu, M.; Zhang, R.; Li, C.; Ji, G.; et al. Sirt3 deficiency exacerbates diabetic cardiac dysfunction: Role of Foxo3A-Parkin-mediated mitophagy. Biochim. Biophys. Acta Mol. Basis Dis. 2017, 1863, 1973-1983. [CrossRef] [PubMed]

76. Bagul, P.K.; Deepthi, N.; Sultana, R.; Banerjee, S.K. Resveratrol ameliorates cardiac oxidative stress in diabetes through deacetylation of NFkB-p65 and histone 3. J. Nutr. Biochem. 2015, 26, 1298-1307. [CrossRef] [PubMed]

77. Wang, B.; Yang, Q.; Sun, Y.; Xing, Y.; Wang, Y.; Lu, X.; Bai, W.; Liu, X.; Zhao, Y. Resveratrol-enhanced autophagic flux ameliorates myocardial oxidative stress injury in diabetic mice. J. Cell. Mol. Med. 2014, 18, 1599-1611. [CrossRef]

78. Olaniyi, K.S.; Amusa, O.A.; Areola, E.D.; Olatunji, L.A. Suppression of HDAC by sodium acetate rectifies cardiac metabolic disturbance in streptozotocin-nicotinamide-induced diabetic rats. Exp. Biol. Med. 2020, 245, 667-676. [CrossRef]

79. Malek, V.; Sharma, N.; Gaikwad, A.B. Histone Acetylation Regulates Natriuretic Peptides and Neprilysin Gene Expressions in Diabetic Cardiomyopathy and Nephropathy. Curr. Mol. Pharmacol. 2019, 12, 61-71. [CrossRef]

80. Xu, Z.; Tong, Q.; Zhang, Z.; Wang, S.; Zheng, Y.; Liu, Q.; Qian, L.; Chen, S.; Sun, J.; Cai, L. Inhibition of HDAC3 prevents diabetic cardiomyopathy in OVE26 mice via epigenetic regulation of DUSP5-ERK1/2 pathway. Clin. Sci. 2017, 131, 1841-1857. [CrossRef]

81. Chen, Y.; Du, J.; Zhao, Y.T.; Zhang, L.; Lv, G.; Zhuang, S.; Qin, G.; Zhao, T.C. Histone deacetylase (HDAC) inhibition improves myocardial function and prevents cardiac remodeling in diabetic mice. Cardiovasc. Diabetol. 2015, 14, 99. [CrossRef] [PubMed]

82. Gaikwad, A.B.; Gupta, J.; Tikoo, K. Epigenetic changes and alteration of Fbn1 and Col3A1 gene expression under hyperglycaemic and hyperinsulinaemic conditions. Biochem. J. 2010, 432, 333-341. [CrossRef] [PubMed]

83. Yu, X.-Y.; Geng, Y.-J.; Liang, J.-L.; Lin, Q.-X.; Lin, S.-G.; Zhang, S.; Li, Y. High levels of glucose induce apoptosis in cardiomyocyte via epigenetic regulation of the insulin-like growth factor receptor. Exp. Cell Res. 2010, 316, 2903-2909. [CrossRef] [PubMed]

84. Thakur, V.; Alcoreza, N.; Cazares, J.; Chattopadhyay, M. Changes in Stress-Mediated Markers in a Human Cardiomyocyte Cell Line under Hyperglycemia. Int. J. Mol. Sci. 2021, 22, 10802. [CrossRef]

85. Shepherd, D.L.; Hathaway, Q.A.; Nichols, C.E.; Durr, A.J.; Pinti, M.V.; Hughes, K.M.; Kunovac, A.; Stine, S.M.; Hollander, J.M. Mitochondrial proteome disruption in the diabetic heart through targeted epigenetic regulation at the mitochondrial heat shock protein 70 (mtHsp70) nuclear locus. J. Mol. Cell. Cardiol. 2018, 119, 104-115. [CrossRef]

86. Yu, X.-Y.; Geng, Y.-J.; Liang, J.-L.; Zhang, S.; Lei, H.-P.; Zhong, S.-L.; Lin, Q.-X.; Shan, Z.-X.; Lin, S.-G.; Li, Y. High levels of glucose induce "metabolic memory" in cardiomyocyte via epigenetic histone H3 lysine 9 methylation. Mol. Biol. Rep. 2012, 39, 8891-8898. [CrossRef]

87. Guo, Y.; Feng, X.; Wang, D.; Kang, X.; Zhang, L.; Ren, H.; Yuan, G. Long Non-coding RNA: A Key Regulator in the Pathogenesis of Diabetic Cardiomyopathy. Front. Cardiovasc. Med. 2021, 8, 8891-8898. [CrossRef]

88. Jakubik, D.; Fitas, A.; Eyileten, C.; Jarosz-Popek, J.; Nowak, A.; Czajka, P.; Wicik, Z.; Sourij, H.; Siller-Matula, J.M.; De Rosa, S.; et al. MicroRNAs and long non-coding RNAs in the pathophysiological processes of diabetic cardiomyopathy: Emerging biomarkers and potential therapeutics. Cardiovasc. Diabetol. 2021, 20, 55. [CrossRef]

89. Rai, A.K.; Lee, B.; Gomez, R.; Rajendran, D.; Khan, M.; Garikipati, V.N.S. Current Status and Potential Therapeutic Strategies for Using Non-coding RNA to Treat Diabetic Cardiomyopathy. Front. Physiol. 2021, 11, 55. [CrossRef]

90. Ahmed, U.; Khaliq, S.; Ahmad, H.U.; Ahmad, I.; Ashfaq, U.A.; Qasim, M.; Masoud, M.S. Pathogenesis of Diabetic Cardiomyopathy and Role of miRNA. Crit. Rev. Eukaryot. Gene Expr. 2021, 31, 79-92. [CrossRef]

91. Hussain, S.; Khan, A.W.; Akhmedov, A.; Suades, R.; Costantino, S.; Paneni, F.; Caidahl, K.; Mohammed, S.A.; Hage, C.; Gkolfos, C.; et al. Hyperglycemia Induces Myocardial Dysfunction via Epigenetic Regulation of JunD. Circ. Res. 2020, 127, 1261-1273. [CrossRef] [PubMed]

92. Costantino, S.; Paneni, F.; Mitchell, K.; Mohammed, S.A.; Hussain, S.; Gkolfos, C.; Berrino, L.; Volpe, M.; Schwarzwald, C.; Lüscher, T.F.; et al. Hyperglycaemia-induced epigenetic changes drive persistent cardiac dysfunction via the adaptor p66 Shc. Int. J. Cardiol. 2018, 268, 179-186. [CrossRef] [PubMed]

93. Vecellio, M.; Spallotta, F.; Nanni, S.; Colussi, C.; Cencioni, C.; Derlet, A.; Bassetti, B.; Tilenni, M.; Carena, M.C.; Farsetti, A.; et al. The Histone Acetylase Activator Pentadecylidenemalonate 1b Rescues Proliferation and Differentiation in the Human Cardiac Mesenchymal Cells of Type 2 Diabetic Patients. Diabetes 2014, 63, 2132-2147. [CrossRef]

94. Friedenstein, A.J.; Chailakhjan, R.K.; Lalykina, K.S. The Development of Fibroblast Colonies in Monolayer Cultures of Guinea-Pig Bone Marrow and Spleen Cells. Cell Prolif. 1970, 3, 393-403. [CrossRef]

95. Kabat, M.; Bobkov, I.; Kumar, S.; Grumet, M. Trends in mesenchymal stem cell clinical trials 2004-2018: Is efficacy optimal in a narrow dose range? Stem Cells Transl. Med. 2020, 9, 17-27. [CrossRef] 
96. Dominici, M.; Le Blanc, K.; Mueller, I.; Slaper-Cortenbach, I.; Marini, F.; Krause, D.S.; Deans, R.J.; Keating, A.; Prockop, D.J.; Horwitz, E.M. Minimal criteria for defining multipotent mesenchymal stromal cells. The International Society for Cellular Therapy position statement. Cytotherapy 2006, 8, 315-317. [CrossRef] [PubMed]

97. Harrell, C.R.; Jankovic, M.G.; Fellabaum, C.; Volarevic, A.; Djonov, V.; Arsenijevic, A.; Volarevic, V. Molecular Mechanisms Responsible for Anti-Inflammatory and Immunosuppressive Effects of Mesenchymal Stem Cell-Derived Factors. Cells 2019, 8 1605. [CrossRef]

98. Ranjbaran, H.; Abediankenari, S.; Khalilian, A.; Rahmani, Z.; Momeninezhad Amiri, M.; Hosseini Khah, Z. Differentiation of Wharton's Jelly Derived Mesenchymal Stem Cells into Insulin Producing Cells. Int. J. Hematol. Stem Cell Res. 2018, 12, $220-229$.

99. Xin, Y.; Jiang, X.; Wang, Y.; Su, X.; Sun, M.; Zhang, L.; Tan, Y.; Wintergerst, K.A.; Li, Y.; Li, Y. Insulin-Producing Cells Differentiated from Human Bone Marrow Mesenchymal Stem Cells In Vitro Ameliorate Streptozotocin-Induced Diabetic Hyperglycemia. PLoS ONE 2016, 11, e0145838. [CrossRef]

100. Wartchow, K.M.; Rodrigues, L.; Suardi, L.Z.; Federhen, B.C.; Selistre, N.G.; Gonçalves, C.-A.; Sesterheim, P. Short-Term Protocols to Obtain Insulin-Producing Cells from Rat Adipose Tissue: Signaling Pathways and In Vivo Effect. Int. J. Mol. Sci. 2019, $20,2458$. [CrossRef]

101. Hsiao, C.-Y.; Chen, T.-H.; Huang, B.-S.; Chen, P.-H.; Su, C.-H.; Shyu, J.-F.; Tsai, P.-J. Comparison between the therapeutic effects of differentiated and undifferentiated Wharton's jelly mesenchymal stem cells in rats with streptozotocin-induced diabetes. World $J$. Stem Cells 2020, 12, 139-151. [CrossRef] [PubMed]

102. Huang, Q.; Huang, Y.; Liu, J. Mesenchymal Stem Cells: An Excellent Candidate for the Treatment of Diabetes Mellitus. Int. J. Endocrinol. 2021, 2021, 9938658. [CrossRef] [PubMed]

103. Gubert, F.; da Silva, J.S.; Vasques, J.F.; de Jesus Gonçalves, R.G.; Martins, R.S.; de Sá, M.P.L.; Mendez-Otero, R.; Zapata-Sudo, G. Mesenchymal Stem Cells Therapies on Fibrotic Heart Diseases. Int. J. Mol. Sci. 2021, 22, 7447. [CrossRef] [PubMed]

104. Quevedo, H.C.; Hatzistergos, K.E.; Oskouei, B.N.; Feigenbaum, G.S.; Rodriguez, J.E.; Valdes, D.; Pattany, P.M.; Zambrano, J.P.; $\mathrm{Hu}, \mathrm{Q}$; McNiece, I.; et al. Allogeneic mesenchymal stem cells restore cardiac function in chronic ischemic cardiomyopathy via trilineage differentiating capacity. Proc. Natl. Acad. Sci. USA 2009, 106, 14022-14027. [CrossRef] [PubMed]

105. Gallina, C.; Turinetto, V.; Giachino, C. A New Paradigm in Cardiac Regeneration: The Mesenchymal Stem Cell Secretome. Stem Cells Int. 2015, 2015, 765846. [CrossRef]

106. Zhang, N.; Li, J.; Luo, R.; Jiang, J.; Wang, J.-A. Bone Marrow Mesenchymal Stem Cells Induce Angiogenesis and Attenuate the Remodeling of Diabetic Cardiomyopathy. Exp. Clin. Endocrinol. Diabetes 2008, 116, 104-111. [CrossRef]

107. Calligaris, S.D.; Conget, P. Intravenous administration of bone marrow-derived multipotent mesenchymal stromal cells has a neutral effect on obesity-induced diabetic cardiomyopathy. Biol. Res. 2013, 46, 251-255. [CrossRef]

108. Dong, X.; Zhu, F.; Liu, Q.; Zhang, Y.; Wu, J.; Jiang, W.; Zhang, L.; Dong, S. Transplanted bone marrow mesenchymal stem cells protects myocardium by regulating 14-3-3 protein in a rat model of diabetic cardiomyopathy. Int. J. Clin. Exp. Pathol. 2014, 7, 3714-3723.

109. Lin, Y.; Zhang, F.; Lian, X.-F.; Peng, W.-Q.; Yin, C.-Y. Mesenchymal stem cell-derived exosomes improve diabetes mellitus-induced myocardial injury and fibrosis via inhibition of TGF- $31 /$ Smad2 signaling pathway. Cell. Mol. Biol. (Noisy-le-Grand) 2019, 65, 123-126. [CrossRef]

110. Ammar, H.I.; Shamseldeen, A.M.; Shoukry, H.S.; Ashour, H.; Kamar, S.S.; Rashed, L.A.; Fadel, M.; Srivastava, A.; Dhingra, S. Metformin impairs homing ability and efficacy of mesenchymal stem cells for cardiac repair in streptozotocin-induced diabetic cardiomyopathy in rats. Am. J. Physiol. Circ. Physiol. 2021, 320, H1290-H1302. [CrossRef]

111. Pappritz, K.; Dong, F.; Miteva, K.; Kovacs, A.; El-Shafeey, M.; Kerim, B.; O’Flynn, L.; Elliman, S.J.; O’Brien, T.; Hamdani, N.; et al. Impact of Syndecan-2-Selected Mesenchymal Stromal Cells on the Early Onset of Diabetic Cardiomyopathy in Diabetic db/db Mice. Front. Cardiovasc. Med. 2021, 8, 632728. [CrossRef] [PubMed]

112. Chu, D.-T.; Nguyen Thi Phuong, T.; Tien, N.L.B.; Tran, D.K.; Minh, L.B.; Van Thanh, V.; Gia Anh, P.; Pham, V.H.; Thi Nga, V. Adipose Tissue Stem Cells for Therapy: An Update on the Progress of Isolation, Culture, Storage, and Clinical Application. J. Clin. Med. 2019, 8, 917. [CrossRef] [PubMed]

113. Jin, L.; Deng, Z.; Zhang, J.; Yang, C.; Liu, J.; Han, W.; Ye, P.; Si, Y.; Chen, G. Mesenchymal stem cells promote type 2 macrophage polarization to ameliorate the myocardial injury caused by diabetic cardiomyopathy. J. Transl. Med. 2019, 17, 251. [CrossRef] [PubMed]

114. Jin, L.; Zhang, J.; Deng, Z.; Liu, J.; Han, W.; Chen, G.; Si, Y.; Ye, P. Mesenchymal stem cells ameliorate myocardial fibrosis in diabetic cardiomyopathy via the secretion of prostaglandin E2. Stem Cell Res. Ther. 2020, 11, 122. [CrossRef]

115. Chen, T.; Chuang, S.; Shen, C.; Ho, T.; Chang, R.; Yeh, Y.; Kuo, C.; Mahalakshmi, B.; Kuo, W.; Huang, C. Antioxidant Sirt1/Akt axis expression in resveratrol pretreated adipose-derived stem cells increases regenerative capability in a rat model with cardiomyopathy induced by diabetes mellitus. J. Cell. Physiol. 2021, 236, 4290-4302. [CrossRef]

116. Xu, X.; Tenth, S.; Tao, L. Adipose-derived mesenchymal stem cells (ADMSCs) protect against hyperglycemia and hyperlipidemiainduced heart failure by inhibiting autophagy-related apoptosis. Res. Sq. 2021, 2021, 1-22. [CrossRef]

117. Khan, M.; Ali, F.; Mohsin, S.; Akhtar, S.; Mehmood, A.; Choudhery, M.S.; Khan, S.N.; Riazuddin, S. Preconditioning diabetic mesenchymal stem cells with myogenic medium increases their ability to repair diabetic heart. Stem Cell Res. Ther. $2013,4,58$. [CrossRef] 
118. De Paula, D.R.M.; Capuano, V.; Filho, D.M.; Carneiro, A.C.D.M.; de Oliveira Crema, V.; de Oliveira, L.F.; Rodrigues, A.R.A.; Montano, N.; da Silva, V.J.D. Biological properties of cardiac mesenchymal stem cells in rats with diabetic cardiomyopathy. Life Sci. 2017, 188, 45-52. [CrossRef]

119. Jin, P.; Zhang, X.; Wu, Y.; Li, L.; Yin, Q.; Zheng, L.; Zhang, H.; Sun, C. Streptozotocin-Induced Diabetic Rat-Derived Bone Marrow Mesenchymal Stem Cells Have Impaired Abilities in Proliferation, Paracrine, Antiapoptosis, and Myogenic Differentiation. Transplant. Proc. 2010, 42, 2745-2752. [CrossRef]

120. Li, J.H.; Zhang, N.; Wang, J.A. Improved anti-apoptotic and anti-remodeling potency of bone marrow mesenchymal stem cells by anoxic pre-conditioning in diabetic cardiomyopathy. J. Endocrinol. Investig. 2008, 31, 103-110. [CrossRef]

121. Delucchi, F.; Berni, R.; Frati, C.; Cavalli, S.; Graiani, G.; Sala, R.; Chaponnier, C.; Gabbiani, G.; Calani, L.; Del Rio, D.; et al Resveratrol Treatment Reduces Cardiac Progenitor Cell Dysfunction and Prevents Morpho-Functional Ventricular Remodeling in Type-1 Diabetic Rats. PLoS ONE 2012, 7, e39836. [CrossRef]

122. ShamsEldeen, A.M.; Ashour, H.; Shoukry, H.S.; Fadel, M.; Kamar, S.S.; Aabdelbaset, M.; Rashed, L.A.; Ammar, H.I. Combined treatment with systemic resveratrol and resveratrol preconditioned mesenchymal stem cells, maximizes antifibrotic action in diabetic cardiomyopathy. J. Cell. Physiol. 2019, 234, 10942-10963. [CrossRef]

123. Chen, T.S.; Liou, S.Y.; Lin, H.H.; Hung, M.Y.; Lin, C.C.; Lin, Y.M.; Lin, K.H.; Padma, V.V.; Yao, C.H.; Kuo, W.W.; et al. Oral administration of green tea Epigallocatechin-3-gallate reduces oxidative stress and enhances restoration of cardiac function in diabetic rats receiving autologous transplantation of adipose-derived stem cells. Arch. Physiol. Biochem. 2021, 127, 82-89. [CrossRef] [PubMed]

124. Meng, K.; Cai, H.; Cai, S.; Hong, Y.; Zhang, X. Adiponectin Modified BMSCs Alleviate Heart Fibrosis via Inhibition TGFbeta1/Smad in Diabetic Rats. Front. Cell Dev. Biol. 2021, 9, 644160. [CrossRef] [PubMed]

125. Nagamura-Inoue, T. Umbilical cord-derived mesenchymal stem cells: Their advantages and potential clinical utility. World J. Stem Cells 2014, 6, 195. [CrossRef] [PubMed]

126. Van Linthout, S.; Hamdani, N.; Miteva, K.; Koschel, A.; Müller, I.; Pinzur, L.; Aberman, Z.; Pappritz, K.; Linke, W.A.; Tschöpe, C. Placenta-Derived Adherent Stromal Cells Improve Diabetes Mellitus-Associated Left Ventricular Diastolic Performance. Stem Cells Transl. Med. 2017, 6, 2135-2145. [CrossRef] [PubMed]

127. Butler, J.; Epstein, S.E.; Greene, S.J.; Quyyumi, A.A.; Sikora, S.; Kim, R.J.; Anderson, A.S.; Wilcox, J.E.; Tankovich, N.I.; Lipinski, M.J.; et al. Intravenous Allogeneic Mesenchymal Stem Cells for Nonischemic Cardiomyopathy. Circ. Res. 2017, 120, 332-340. [CrossRef]

128. Xiao, W.; Guo, S.; Gao, C.; Dai, G.; Gao, Y.; Li, M.; Wang, X.; Hu, D. A Randomized Comparative Study on the Efficacy of Intracoronary Infusion of Autologous Bone Marrow Mononuclear Cells and Mesenchymal Stem Cells in Patients with Dilated Cardiomyopathy. Int. Heart J. 2017, 58, 238-244. [CrossRef]

129. Tompkins, B.A.; Rieger, A.C.; Florea, V.; Banerjee, M.N.; Natsumeda, M.; Nigh, E.D.; Landin, A.M.; Rodriguez, G.M.; Hatzistergos, K.E.; Schulman, I.H.; et al. Comparison of Mesenchymal Stem Cell Efficacy in Ischemic Versus Nonischemic Dilated Cardiomyopathy. J. Am. Heart Assoc. 2018, 7, e008460. [CrossRef]

130. Hare, J.M.; DiFede, D.L.; Rieger, A.C.; Florea, V.; Landin, A.M.; El-Khorazaty, J.; Khan, A.; Mushtaq, M.; Lowery, M.H.; Byrnes, J.J.; et al. Randomized Comparison of Allogeneic Versus Autologous Mesenchymal Stem Cells for Nonischemic Dilated Cardiomyopathy. J. Am. Coll. Cardiol. 2017, 69, 526-537. [CrossRef]

131. Premer, C.; Wanschel, A.; Porras, V.; Balkan, W.; Legendre-Hyldig, T.; Saltzman, R.G.; Dong, C.; Schulman, I.H.; Hare, J.M. Mesenchymal Stem Cell Secretion of SDF-1 $\alpha$ Modulates Endothelial Function in Dilated Cardiomyopathy. Front. Physiol. 2019, 10, 1182. [CrossRef] [PubMed]

132. Golpanian, S.; El-Khorazaty, J.; Mendizabal, A.; DiFede, D.L.; Suncion, V.Y.; Karantalis, V.; Fishman, J.E.; Ghersin, E.; Balkan, W.; Hare, J.M. Effect of Aging on Human Mesenchymal Stem Cell Therapy in Ischemic Cardiomyopathy Patients. J. Am. Coll. Cardiol. 2015, 65, 125-132. [CrossRef] [PubMed]

133. Florea, V.; Rieger, A.C.; Natsumeda, M.; Tompkins, B.A.; Banerjee, M.N.; Schulman, I.H.; Premer, C.; Khan, A.; Valasaki, K.; Heidecker, B.; et al. The impact of patient sex on the response to intramyocardial mesenchymal stem cell administration in patients with non-ischaemic dilated cardiomyopathy. Cardiovasc. Res. 2020, 116, 2131-2141. [CrossRef] [PubMed]

134. Cho, J.; D’Antuono, M.; Glicksman, M.; Wang, J.; Jonklaas, J. A review of clinical trials: Mesenchymal stem cell transplant therapy in type 1 and type 2 diabetes mellitus. Am. J. Stem Cells 2018, 7, 82-93. [PubMed] 